\title{
Modelling the potential for permafrost development on a radioactive waste geological disposal facility in Great Britain
}

\author{
Busby $\mathrm{J} \mathrm{P}^{1^{*}}$, Lee $\mathrm{J} \mathrm{R}^{1}$, Kender $\mathrm{S}^{1}$, Williamson $\mathrm{J}^{1}$ and Norris $\mathrm{S}^{2}$ \\ ${ }^{1}$ British Geological Survey, Keyworth, Nottingham, NG12 5GG, UK \\ ${ }^{2}$ Radioactive Waste Management Limited, Curie Avenue, Harwell, Didcot, OX11 ORA \\ * corresponding author; email jpbu@bgs.ac.uk
}

Keywords: Permafrost, modelling, predictions, radioactive waste geological disposal

\begin{abstract}
The safety case for a geological disposal facility (GDF) for radioactive waste based in Great Britain must consider the potential impact on the repository environment of permafrost during the $1 \mathrm{M}$ yrs following GDF closure. The depth of penetration of permafrost, defined as ground which remains at or below $0^{\circ} \mathrm{C}$ for at least two consecutive years, has been modelled for a future climate that uses the climate of the last glacial-interglacial cycle as an analogue. Two future climates are considered; an average estimate case considered to be the best estimate of ground surface temperatures during the last glacial-interglacial cycle, and a cold estimate case considered to be an extreme cold, but plausible future climate. Maximum modelled permafrost thicknesses across Great Britain range from 20-180 m for the average estimate climate and 180-305 $\mathrm{m}$ for the cold estimate climate. The presence of ice cover is an important determinant on permafrost development. Thick permafrost evolves during long periods of cold-based ice cover and during periods of ice retreat that results in ground exposure to very cold air temperatures. Conversely, warm-based ice has an insulating effect, shielding the ground from cold air temperatures that retards permafrost development. For a GDF at a depth greater than that predicted to be directly affected by permafrost, phenomena associated with permafrost, e.g., enhanced groundwater salinity at depth, will need to be taken into account when considering the impact on the engineered and natural barriers associated with a GDF.
\end{abstract}

\section{Introduction}

A geological disposal facility (GDF) for radioactive waste is based upon a multi-barrier system that combines a series of engineered and natural barriers to isolate the wastes and contain the radionuclides associated with the wastes (Chapman and Hooper, 2011). The depth of the GDF is dependent on minimising the impact of external environmental processes, such as those associated with climate change. Post-closure safety case studies typically consider such natural changes over the first one million years following GDF closure. Perennially frozen ground has been identified as one of a number of natural processes that could affect a GDF over such a time scale (e.g. Chapman and Hooper, 2011; Shaw et al., 2012). It is still uncertain as to the significance and impact of frozen ground on the long-term physical and chemical stability of the repository environment (EC, 2008: Loew et al., 2008: Miller, 2012). There may be a number of geophysical and geochemical changes to the geological barrier induced by freezing, including: (1) the thermo-hydro-mechanical impact on the host rock stress induced by freeze/thaw conditions; (2) a change in the regional and local groundwater flow paths; (3) the formation of taliks (unfrozen ground beneath lakes) that could act as points for radionuclide releases to the surface; (4) increased groundwater salinity due to salt exclusion in freezing that may also give rise to density-driven flow at depth; (5) intrusion of freshwater during melting; (6) formation and destabilisation of gas hydrates that could form 
beneath the frozen layer. In-turn, the hydromechanical and geochemical properties of the engineered barrier system (which could contain significant amounts of bentonite and/or concrete/cement) may be impacted by freezing in several different ways such as: (1) longterm performance during transient periods with high hydraulic, thermal or chemical gradients, which could influence the evolution of repository components; (2) highly-saline residual brine, produced during the formation of frozen ground, that may affect the swelling characteristics of bentonite and the stability of cement. The development of frozen ground could affect the properties of rocks above a GDF leading to the possible development of new fracture pathways affecting groundwater recharge and discharge. Frozen ground will create a barrier to groundwater flow, but once the ground has thawed its permeability may be increased leading to temporary or permanent changes to groundwater flow paths.

This paper investigates the potential for permafrost development across Great Britain under possible future climate scenarios. It follows a previous modelling study on permafrost thickness during the last glacial-interglacial cycle (Busby et al., in press). It is non site specific, but a series of locations have been selected in order that a range of geographical and geological settings can be considered. The modelling is at the regional scale with a focus on the maximum depth extent to which permafrost might develop in an average future climate and in an extreme (cold) climate up to three hundred thousand years into the future.

\section{Permafrost modelling approach}

The definition of permafrost applied here is ground which remains at or below $0^{\circ} \mathrm{C}$ for at least two consecutive years (French, 2007) as opposed to perennially frozen ground that keeps frozen for at least two consecutive years. Hence, permafrost is defined on the basis of temperature, thus disregarding the texture, degree of compaction, water content, and lithologic character of the material, whereas perennially frozen ground is defined on the basis of the freezing of water. The freezing of water is itself dependent on pressure, salinity and the adsorptive and capillary properties of the ground matter.

The modelling is based on the periodic heating at the surface of a column of infinite depth and the propagation of the heat into the ground in the vertical (depth) dimension. This one dimensional heat conduction approach does not take into account the freezing of water, the effect of groundwater movement or the change in ground properties due to freezing. Carslaw and Jaeger (1959) have shown that

$$
T_{\theta}=T_{0} \times \operatorname{erfc}[z / 2 \sqrt{\kappa t}],
$$

where $T_{\theta}$ is the departure from original equilibrium temperature at depth $\mathrm{z}$ and time $\mathrm{t}$ after an instantaneous change in surface temperature of $T_{0}, \kappa$ is the average thermal diffusivity of the geological strata down to depth $\mathrm{z}$ and $\operatorname{erfc}(\mathrm{x})$ is the complementary error function. Noting that the change in surface temperature is the difference in temperature between successive steps, the effect of more than one temperature step is found by addition of all the steps, i.e.

$$
\mathrm{T}_{\theta}=\sum \mathrm{T}_{\theta \mathrm{i}},
$$

where $T_{\theta i}$ is the temperature deviation due to the ith event.

The approach here has been to use the last glacial-interglacial cycle as an analogue for future climate and therefore to model permafrost evolution over the period of the last glacialinterglacial cycle. To model the evolution of ground sub-surface temperatures through time, an initial sub-surface temperature profile is perturbed by any step changes in surface 
temperature that have occurred from the initial time up to the time being considered. The initial time has been taken at $126 \mathrm{kyr}$ BP (Before Present) and sub-surface temperatures have been calculated at $5 \mathrm{~m}$ depth intervals to $1 \mathrm{~km}$ every $250 \mathrm{yrs}$ up to present day.

\section{Future climate}

When we consider future climate, one approach is to consider what has happened in the past, on the assumption that it will repeat in the future. The climate over the last $\sim 1$ million years in northern Europe has experienced a series of cold spells, broadly every $100 \mathrm{kyr}$. Superimposed upon these large-scale glacial cycles are more medium-term climatic events occurring with a $\sim 40$ kyr periodicity (Lisiecki \& Raymo 2005). The last glacial stage, called the Devensian Glaciation, was one of the most intense glacial events to affect Great Britain and hence can be used as a suitable analogue for modelling the development of permafrost during a similar-scale cold-event over the next $\sim 300$ kyrs. Since the beginning of the Industrial Revolution this natural climate system has been modified by increased greenhouse gas emissions, which are set to cause significant warming of the climate in the relatively near future (IPCC, 2013). However, over the long term (>10s to 100s kyr) modelling studies suggest that the climate will return to past glacial-interglacial background conditions (BIOCLIM, 2001). This conclusion is supported by palaeoclimate proxy data over past 'hyperthermal' episodes (e.g. at the Palaeocene-Eocene Thermal Maximum), which show that Earth's climate returned to background temperature levels within $200 \mathrm{kyr}$ after significant atmospheric $\mathrm{CO}_{2}$ release and global warming (DeConto et al. 2012).

The mean annual air temperature (MAAT) for Great Britain over the last glacial-interglacial cycle (0-130 kyr ago) has been constructed from multiple proxy data comprising NE Atlantic sea surface temperature (SST) and pollen-based MAAT proxies to reconstruct an idealized temperature curve. The detail of this procedure was presented in Busby et al. (in press) and is not repeated here. The result is an idealised MAAT profile that is shown in Figure 1. It is necessary to scale this profile to account for the variation in latitude between southern and northern Britain. Present day MAAT is the maximum temperature and is taken as the Holocene average, whilst the minimum MAAT is from the Annan and Hargreaves (2013) global estimate of MAAT during the global peak of the last glaciation (19-23 kyr BP). Therefore the minimum MAAT for southern England and Wales localities are estimated to be $8-12^{\circ} \mathrm{C}$ below present, and the northern England and Scotland sites $12-20^{\circ} \mathrm{C}$ below present. Two climate models have been applied; the first is an average estimate (AE) case considered to be the best estimate of ground surface temperatures during the last glacial-interglacial cycle where the climate range is $12^{\circ} \mathrm{C}$ to $17^{\circ} \mathrm{C}$ below modern, between southern English and northern Scottish sites respectively. The second climate is a cold estimate (CE) case considered to be an extreme cold, but plausible future climate. The cold estimate climate is towards the cold extreme of the error range reported by Annan and Hargreaves (2013) and ranges between $18^{\circ} \mathrm{C}$ and $27^{\circ} \mathrm{C}$ below modern, between southern English and northern Scottish sites respectively.

The temperature at the ground surface will also be affected by ice sheet and glacier ice cover. Ice extent during the Late Devensian has been modelled by several studies (e.g. Siegert and Dowdeswell, 2004; Hubbard et al., 2009; Evans et al, 2009; Clark et al., 2012). The model reconstructions of Hubbard et al. (2009) provide a series of time-slices that document the growth and decay of the Last British-Irish Ice Sheet extending back to $35 \mathrm{kyr}$ BP. For the period prior to $35 \mathrm{kyr} \mathrm{BP}$, ice cover is assumed whenever the MAAT falls below the temperature where ice cover is predicted for the period since $35 \mathrm{kyr} \mathrm{BP}$. The temperature at the base of the ice is warmer for warm-based ice, which is often found under thick ice in 
topographical troughs, than cold-based ice frozen to its bed. Hall and Glasser (2003) have shown that during basal-freezing conditions, basal temperatures can range from $-12^{\circ} \mathrm{C}$ to $-6^{\circ} \mathrm{C}$ (absolute). However, when basal melting occurs, basal temperatures are more likely to be in the range of $-1^{\circ} \mathrm{C}$ to $+1^{\circ} \mathrm{C}$ (absolute). The procedure for assigning basal ice temperatures is the same as that used by Busby et al. (in press) whereby the British-Irish Ice Sheet modelling of Hubbard et al. (2009) is used to predict if cold-based or warm-based conditions are more likely. Basal absolute temperatures for cold-based frozen conditions are therefore estimated as $-3^{\circ} \mathrm{C}$ for the average estimate surface temperature history and $-4^{\circ} \mathrm{C}$ for the cold estimate case. For warm-based ice conditions, absolute temperatures are assumed to be $+1^{\circ} \mathrm{C}$ for the average estimate surface temperature history and $-1^{\circ} \mathrm{C}$ for the cold estimate case. Application of this concept to two examples within the modelling exercise for the average estimate climate (see Figure 2) reveals that for the Weald (which has never been glaciated), a minimum surface temperature of $12^{\circ} \mathrm{C}$ below present occurred during the climatic minimum between, approximately, 19 and $30 \mathrm{kyr}$ BP. Alternatively, within the Southern Uplands example, the land-surface is modelled to have been insulated from the minimum MAAT of $17^{\circ} \mathrm{C}$ below present by extensive phases of ice-sheet cover. These occur between 110-102, 76-37 and 34-14.5 kyr BP and the temperature is constant at $-3^{\circ} \mathrm{C}$ absolute $\left(10.8^{\circ} \mathrm{C}\right.$ below present). The minimum surface temperature of $11.9^{\circ} \mathrm{C}$ below present occurred between $13-12$ kyr BP after the ice had retreated.

\section{Permafrost modelling locations}

In order to assess how permafrost development may vary across Great Britain, ten locations have been selected which present a variety of latitudes, elevations and geological sequences. These are shown in Figure 3. For each location, the vertical geological bedrock section, at the 1:625 000 scale, has been extracted to $1 \mathrm{~km}$ depth from the BGS GB3D national geological model (Mathers et al., 2014). In summary these locations comprise;

\begin{tabular}{|c|c|}
\hline Dartmoor & Permian granite pluton \\
\hline Weald & Mesozoic argillaceous, arenaceous and limestone rocks \\
\hline East Anglia & $\begin{array}{l}\text { Chalk and Mesozoic argillaceous rocks overlying Lower Palaeozoic } \\
\text { basement }\end{array}$ \\
\hline South Midlands & $\begin{array}{l}\text { Argillaceous Jurassic and Triassic rocks overlying Lower Palaeozoic } \\
\text { basement }\end{array}$ \\
\hline Mid-Wales & Silurian mudstone, sandstone, siltstone and conglomerate \\
\hline South Yorkshire & Carboniferous Coal Measures overlying Millstone Grit \\
\hline Stainmore Trough & Carboniferous sedimentary rocks of mixed lithologies \\
\hline Southern Uplands & Silurian greywacke \\
\hline Midland Valley & $\begin{array}{l}\text { Carboniferous Coal Measures and Clackmannan Group limestone, } \\
\text { sandstone and mudstone }\end{array}$ \\
\hline
\end{tabular}

Table 1 details the geological succession at each locality and includes the thermal conductivity of the strata (Rollin 2002), the mean annual present day ground surface temperature, estimated heat flow (Busby et al. 2011) and assumed periods of ice cover during the last glacial-interglacial cycle.

\section{Permafrost modelling results}


Permafrost evolution over time has been modelled with the repeated application of equation

$$
\operatorname{grad} T_{z}=-\frac{q}{\lambda_{z}},
$$

where $\operatorname{grad} T_{z}$ is the temperature gradient $\left(\mathrm{K} \mathrm{m}^{-1}\right)$ between depths $\mathrm{z}_{\mathrm{i}}$ and $\mathrm{z}_{\mathrm{i}+1}, \mathrm{q}$ is the heat flow $\left(\mathrm{W} \mathrm{m}^{-2}\right)$ and $\lambda_{\mathrm{z}}$ is thermal conductivity $\left(\mathrm{W} \mathrm{m}^{-1} \mathrm{~K}^{-1}\right.$ ) between depths $\mathrm{z}_{\mathrm{i}}$ and $\mathrm{z}_{\mathrm{i}+1}$. This is applied from the ground surface downwards where, from the derivation of the surface temperature histories discussed above, the initial ground surface temperatures at $130 \mathrm{kyr}$ BP have been taken to be $5{ }^{\circ} \mathrm{C}$ less than present day at all ten locations. The possibility that these initial temperature profiles might be influenced by the previous glacial-interglacial cycle is considered in section 5.3.

\subsection{Regional results}

The evolution of sub-surface temperatures (i.e. temperatures beneath the ground surface) as a result of the surface temperature histories for both the $\mathrm{AE}$ and $\mathrm{CE}$ climates has been modelled with sub-surface temperatures generated every 250 years from $126 \mathrm{kyr}$ BP to present day. Example plots of the sub-surface temperatures for the Weald and Southern Uplands are shown in Figures 4 and 5 where permafrost $\left(\mathrm{T} \leq 0^{\circ} \mathrm{C}\right)$ is shown as shades of blue/cyan. At the southerly Weald location permafrost development in the AE climate was not extensive. An absence of ice cover has resulted in maximum permafrost thicknesses, during the Late Devensian climatic minimum, of $65 \mathrm{~m}$ for the AE climate and $245 \mathrm{~m}$ for the CE climate. At the northerly Southern Uplands location, MAAT has been estimated to be $5^{\circ} \mathrm{C}$ and $9^{\circ} \mathrm{C}$ less than at southern locations, for the $\mathrm{AE}$ and $\mathrm{CE}$ climates respectively. However, the landsurface has been insulated from these coldest temperatures by extensive periods of ice-sheet cover. It has been assumed that in the Southern Uplands this ice would have been cold-based leading to extensive periods of permafrost, but the deepest permafrost development of $150 \mathrm{~m}$ and $305 \mathrm{~m}$ for the $\mathrm{AE}$ and $\mathrm{CE}$ climates respectively, occurs at around $12.5 \mathrm{kyr} \mathrm{BP}$ after the land-surface becomes ice free at $14.5 \mathrm{kyr}$ BP. It should also be noted at the Southern Uplands location that the relative permafrost evolution through time varies between the $\mathrm{AE}$ and $\mathrm{CE}$ climates. For instance, between 76-94 kyr BP the permafrost is thicker during the unglaciated period in the CE climate, but is thinner in the AE climate. This occurs because in the $\mathrm{CE}$ climate the MAAT is colder than the basal ice temperature in contrast to the AE climate where it is warmer. Maximum depths of permafrost at the ten locations are shown in Table 2.

\subsection{Short-term effects}

In the regional modelling a series of step changes in surface temperature have been taken to represent cyclical events. For cyclical events, the development of glacier ice is likely to be coincident with the onset of cold conditions and this is implicit in the modelled sampling period of 250 years. However, there is strong evidence that the onset of glaciations can be very rapid and of the order of tens to hundreds of years, often linked to abrupt changes in oceanic (thermohaline) circulation (Prueher and Rea, 1998; Rahmstorf, 2002). Hence, given the lag-time between the onset of very cold conditions and ice-sheet expansion, the landsurface may be exposed to the cold extremes of the MAAT that could lead to the development of short-lived, but thick permafrost. This has been explored in a theoretical situation for one location only, the Southern Uplands, where under these conditions the deepest permafrost development would be expected as it has been assumed that it was exposed to the coldest MAAT and the thermal conductivity of the geological succession is high at this location. 
In the surface temperature history for the Southern Uplands (Figure 2b) there is an ice-free assumes that at $34 \mathrm{kyr}$ BP the land-surface is exposed to the coldest MAAT $\left(-17^{\circ} \mathrm{C}\right.$ relative to modern; $-9.2^{\circ} \mathrm{C}$ absolute for the $\mathrm{AE}$ climate and $-27^{\circ} \mathrm{C}$ relative to modern; $-19.2^{\circ} \mathrm{C}$ absolute for the CE climate) for 50, 100, 200 and 500 years before the development of glacier ice. This is a theoretical situation to explore maximum possible permafrost depths as during the last glacial cycle at the Southern Uplands the temperature step at $34 \mathrm{kyr}$ BP would have reduced surface temperatures to $-12.9^{\circ} \mathrm{C}$ relative to modern for the $\mathrm{AE}$ climate and $-20.5^{\circ} \mathrm{C}$ relative to modern for the CE climate. The modelling has been run from 40-31 kyr BP at 10 year intervals and for increasing exposure (50-500 years) of the land-surface to ice-free conditions, resulting in maximum permafrost thicknesses of $100,125,150$ and $190 \mathrm{~m}$ for the AE climate and 220, 240, 265 and $315 \mathrm{~m}$ for the CE climate (Figure 6).

\subsection{Impact of the last two glacial-interglacial cycles}

The permafrost modelling at the ten locations has been based on a surface temperature history from the last glacial-interglacial cycle. The coldest temperatures experienced in Great Britain during the last glaciation occurred at the Late Devensian climatic minimum and the deepest permafrost modelled corresponds to this period unless insulated by ice cover. Previous glacial-interglacial cycles, although not as cold as the Late Devensian climatic minimum, will have imposed a thermal imprint into the sub-surface that may alter the modelled permafrost depths if only the last glacial-interglacial cycle is considered.

A permafrost evolution model has been run for the Dartmoor location with a surface temperature history from $212 \mathrm{kyr}$ BP to present that is shown in Figure 7. The extension to $212 \mathrm{kyr}$ BP incorporates the last two glacial-interglacial cycles. It utilises the SST reconstruction from ODP (Ocean Drilling Program) ocean core 980 (McManus et al., 1999). Two cases have again been considered, the average estimate case with a minimum MAAT of $-12^{\circ} \mathrm{C}$ (relative to present day) and a cold estimate case with a minimum MAAT of $-18^{\circ} \mathrm{C}$ (relative to present day). From the palaeoclimate reconstruction the surface temperature at $212 \mathrm{kyr}$ BP has been estimated to be equivalent to present day and hence the initial subsurface temperature profile has been estimated assuming a surface temperature of $9^{\circ} \mathrm{C}$, the present day value for Dartmoor. The heat flow has been assumed to be constant at $0.105 \mathrm{~W}$ $\mathrm{m}^{-2}$.

The modelling has been performed every 250 years and the results are shown in Figures $8 \mathrm{a}$ and $b$ with temperatures plotted to $1000 \mathrm{~m}$ depth. It can be seen that there is no influence of the previous glacial cycle on the last glacial cycle and maximum depths of permafrost during the last glaciation are $75 \mathrm{~m}$ and $220 \mathrm{~m}$ for the average and cold estimate surface temperature histories respectively, which is in agreement with depths modelled when only considering the last glacial-interglacial cycle.

\subsection{Impact of anthropogenic warming}

The models run have used the last glacial-interglacial cycle(s) as an analogue for future climate. However, future climate will be affected by present day anthropogenic warming. Shaw et al. (2012) report that glacial cyclicity will return to dominate global climate, but not until the effects of anthropogenic warming have receded. One plausible model (BIOCLIM, 2001) comprises rapid (century scale) warming of $3^{\circ} \mathrm{C}$ after which the climate returns to present day temperatures by $90 \mathrm{kyr}$ AP (After Present) with the onset of the first Northern Hemisphere glaciations between about 170 and $180 \mathrm{kyr}$ AP. A surface temperature prediction based on this model is shown in Figure 9, where a $3^{\circ} \mathrm{C}$ rise of temperature over present day 
decays back to present day temperatures in equal $0.5^{\circ} \mathrm{C}$ increments by $90 \mathrm{kyr} \mathrm{AP}$, until the last glacial-interglacial cycle repeats from $170 \mathrm{kyr}$ AP.

From an initial (present day) sub-surface temperature profile that comprises the climate corrected estimated temperature (the modelled temperature from the last glacial-interglacial cycle at present day), the future permafrost evolution at the Dartmoor location has been modelled. Two cases have again been considered, the average estimate case with a minimum MAAT of $-12^{\circ} \mathrm{C}$ (relative to present day) and a cold estimate case with a minimum MAAT of $-18^{\circ} \mathrm{C}$ (relative to present day).

The modelling has been performed every 500 years to $300 \mathrm{kyr}$ AP and the results are shown in Figures 10a and b. After an initial period of warmer sub-surface temperatures the onset of glacial conditions leads to permafrost development as was observed in the models from the last glacial-interglacial cycle. The maximum depths of permafrost are slightly greater at $90 \mathrm{~m}$ and $255 \mathrm{~m}$ for the average and cold estimate surface temperature predictions respectively. This slight increase in permafrost depth is a result of a different ground temperature profile at the start of the glaciation.

\section{Discussion}

When assessing the impact of permafrost on a GDF there are two primary considerations. Firstly, is shallow permafrost development possible that may lead to changes in groundwater movement and salinity levels? Secondly, is there a possibility that any permafrost might extend to GDF depth and compromise both the engineered and natural barriers? The permafrost modelling for the average estimate climate has indicated permafrost development at all locations. Where the conditions are ice-free this occurs at the Late Devensian climatic minimum. The location with the thinnest permafrost, of $20 \mathrm{~m}$, for the average estimate climate is the Stainmore Trough. Although this is at a northerly latitude, the ground was insulated from the minimum air temperature by warm-based, fast-flowing, glacier ice during the Late Devensian (Evans et al. 2009; Livingstone et al. 2012). The greatest thickness of permafrost for the average estimate climate occurs at the Northwest Highlands location. An extensive period of ice cover also insulated the ground from the coldest air temperatures, but the frozen basal conditions of $-3^{\circ} \mathrm{C}$ (absolute) resulted in a maximum depth of permafrost of $180 \mathrm{~m}$. There is little published evidence relating to the geological signature of permanently frozen ground with which to compare these modelled permafrost depths. However, Hutchison (1991) reports deep periglacial disturbances of up to $62 \mathrm{~m}$ in the Derbyshire area and $47 \mathrm{~m}$ in the Weald. These can be compared to modelled depths for the AE climate from South Yorkshire $(90 \mathrm{~m})$ and the Weald $(65 \mathrm{~m})$. Given that permafrost $\left(\mathrm{T} \leq 0^{\circ} \mathrm{C}\right)$ will be deeper than perennially frozen ground (due to latent heat of freezing, salinity of groundwater etc.) there is a fairly close correspondence between these reported and modelled permafrost depths.

The cold estimate climate is also based on the climate of the last glacial cycle, but is considered to be an extreme cold, but plausible, future climate. For this climate, extensive permafrost development is seen at all localities. The shallowest development occurs in the South Midlands and South Yorkshire and the deepest in the Southern Uplands. It might be expected that the deepest development would be in the Northwest Highlands, but ice cover is predicted until $12 \mathrm{kyr}$ BP, whereas the Southern Uplands are assumed to be ice free by 14.5 kyr BP, exposing the land surface to extremely cold temperatures. Similarly, deep permafrost is predicted at the Stainmore Trough locality, where minimal permafrost was modelled for the average estimate climate case. Again, this locality is predicted to be ice free by $14.5 \mathrm{kyr}$ $\mathrm{BP}$, exposing the ground surface to the very cold temperatures of the cold estimate climate. 
Exposing the land surface to the coldest conditions for short periods of time, as could occur

7.

\section{Conclusions}

One dimensional heat conduction modelling has shown that by assuming past climate can be taken as an analogue for future climate, permafrost development should be taken into consideration when constructing the safety case for a GDF based in Great Britain. For a future climate, considered to be an average representation of the last glacial-interglacial cycle, permafrost developed at all localities with maximum thicknesses varying between 20$180 \mathrm{~m}$. For a climate, also based on the last glacial-interglacial cycle, but defined as an extreme cold, plausible, future climate, maximum permafrost thickness varied between 180$305 \mathrm{~m}$. In general, the greatest maximum permafrost thicknesses occur in northern Britain. This arises from colder northern air temperatures and long periods of ice cover associated with cold, frozen basal conditions. As only ground temperature has been modelled, it is not possible to make any statements about ice formation or the depth that partially or completely frozen ground might penetrate to. However, as shown in other studies (e.g. Hartikainen et al., 2010; Govaerts et al., 2011), perennially frozen ground is likely to correlate with the extent of the ground below $0^{\circ} \mathrm{C}$.

A GDF based in Great Britain is being considered in the depth of 200-1000 m. Modelling has demonstrated that were a GDF to be at relatively shallow depth, permafrost could have a direct impact. Permafrost has the potential to affect the properties of rocks above a GDF, 
leading potentially to the development of new fracture pathways, affecting groundwater recharge and discharge. Changes to groundwater chemistry, particularly salinity, could occur that might result in changes to, e.g., geochemical conditions at GDF depth.

Predictions on permafrost depths and extent are far more uncertain for particular localities than general statements referring to southern and northern Britain. This is due to uncertainties in the minimum MAAT during the last glacial cycle, the extent and thickness of ice cover, particularly in the period prior to $35 \mathrm{kyr} \mathrm{BP}$, and the temperatures at the base of the ice over time. For instance, Govaerts et al. (2011) in their 'realistic glacial cycle' indicated a minimum temperature in northern Belgium (which would be expected to be similar to southern England) of $-19^{\circ} \mathrm{C}$ (relative to present day) and Westaway and Younger (2013) have suggested that during the last glacial-interglacial cycle temperatures in southern England reached $-20^{\circ} \mathrm{C}$ (relative to present day). These are both colder than the climate reconstruction used here and indicate that further research based on climate proxies from the British Isles is needed to generate a more constrained estimate of MAAT for the last glacial-interglacial cycle. Similarly, since ice cover has a major effect in determining permafrost thickness, especially as an insulator against extremely cold MAAT, greater controls on ice cover and thickness are needed for site specific permafrost determinations.

\section{Acknowledgments}

Radioactive Waste Management Limited (RWM) is thanked for their financial support for this study, which also benefitted from review comments from RWM staff and RWM external reviewers. Dr Andrew Finlayson is thanked for his helpful discussions. This paper is published by permission of the Executive Director of the British Geological Survey (NERC).

\section{References}

Annan, J.D., Hargreaves, J.C., 2013. A new global reconstruction of temperature changes at the Last Glacial Maximum. Clim. Past, 9, 367-376.

BIOCLIM, 2001. Deliverable D3: Global Climatic Features over the Next Million Years and Recommendation for Specific Situations to be Considered. Report of the European Commission BIOCLIM Project Modelling Sequential Biosphere Systems under Climate Change for Radioactive Waste Disposal.

Busby, J., Kingdon, A., Williams, J., 2011. The measured shallow temperature field in Britain. Quarterly Journal of Engineering Geology and Hydrogeology, 44, 373-387.

Busby, J.P., Lee, J.R., Kender, S., Williamson, J.P. Norris, S., (in press) Regional modelling of permafrost thicknesses over the past $130 \mathrm{kyr}$ : implications for permafrost development in Great Britain. Boreas

Carslaw, H.A. Jaeger, J.C. 1959., Conduction of heat in solids. $2^{\text {nd }}$ ed. Oxford: Oxford University Press.

Chapman, N., Hooper, A., 2012. The disposal of radioactive wastes underground. Proceedings of the Geologist's Association, 123, 46-63.

Clark, C.D., Hughes, A.L., Greenwood, S.L., Jordan, C., Sejrup, H.P., 2012. Pattern and timing of retreat of the last British-Irish Ice Sheet. Quaternary Science Reviews, 44, 112-146.

DeConto, R.M., Galeotti, S., Pagani, M., Tracy, D., Schaefer, K., Zhang, T., Pollard, D. Beerling, D., 2012. Past extreme warming events linked to massive carbon release from thawing permafrost. Nature, 484, 87-92.

European Commission, 2008. Seventh European Commission Conference on the Management and Disposal of Radioactive Waste - Euradwaste ' 08 - Conference Summaries, Community Policy and Training Activities, October 2008, Luxemburg, 13 p. 
Evans, D.J.A., Livingstone, S.J., Vieli, A., Cofaigh, C.Ó., 2009. The palaeoglaciology of the central sector of the British and Irish Ice Sheet: reconciling glacial geomorphology and preliminary ice sheet modelling. Quaternary Sciences Reviews, 28, 739-757.

French, H.M., 2007. The periglacial environment. (Wiley.) ISBN 0470865903.

Hall, A.M. and Glasser, N.F., 2003. Reconstructing the basal thermal regime of an ice stream in a landscape of selective linear erosion: Glen Avon, Cairngorm Mountains, Scotland. Boreas, 32, 191-207.

Hartikainen, J., Kouhia, R., Wallroth, T., 2010. Permafrost simulations at Forsmark using a numerical 2D thermo-hydro-chemical model. SKB TR-09-17, Svensk Kärnbränslehantering AB.

Hubbard, A., Bradwell, T., Golledge, N., Hall, A., Patton, H., Sugden, D., Cooper, R., Stoker, M., 2009. Dynamic cycles, ice streams and their impact on the extent, chronology and deglaciation of the BritishIrish ice sheet. Quaternary Science Reviews, 28, 758-776.

Hutchinson, J.N. 1991. Theme Lecture: Periglacial and slope processes. In: Forster, G.A., Culshaw, M.G., Cripps, J.C., Little, J.A., Moon, C.F. Quaternary Engineering Geology: Proceedings of the $25^{\text {th }}$ Annual Conference of the Engineering Group of the Geological Society, Heriot-Watt University, Edinburgh, 1014 September 1989. Geological Society, London, Engineering Geology Special Publication,7, 283-331.

Govaerts, J., Weetjens, E., Beerten, K., 2011. Numerical simulation of permafrost depth at the Mol site, External Report of the Belgian Nuclear Research Centre, Mol, Belgium, SCK•CEN-ER-148.

IPCC., 2013. Climate Change 2013: The Physical Science Basis. Contribution of Working Group I to the Fifth Assessment Report of the Intergovernmental Panel on Climate Change [Stocker, T.F, Qin, D., Plattner, G-K., Tignor, M., Allen, S.K., Boschung, J., Nauels, A., Xia, Y., Bex, V., Midgley, P.M. (eds.)]. Cambridge University Press, Cambridge, United Kingdom and New York, NY, USA, 1535 pp.

Lisiecki, L.E., Raymo, M.E., 2005. A Pliocene-Pleistocene stack of 57 globally distributed benthic d ${ }^{18} \mathrm{O}$ records. Paleoceanography, 20, PA1003 1-17.

Livingstone, S.J., Evans, D.J., Ó Cofaigh, C., Davies, B.J., Merritt, J.W., Huddart, D., Mitchell, W.A., Roberts, D.H., Yorke, L., 2012: Glaciodynamics of the central sector of the last British-Irish Ice Sheet in Northern England. Earth-Science Reviews 111, 25-55.

Loew, S., Bluemling, P., Johnson, L., Lemmens, K., Savage, D., Iseghem, P.V., 2008. Report on the panel discussion: "Key Remaining Research Issues in the Area of Near-Field Processes Relevant for the Geological Disposal of High Level Radioactive Wastes". Euradwaste '08: Seventh European Commission Conference on the Management and Disposal of Radioactive Waste, 20-22 October 2008, Luxembourg, $4 \mathrm{p}$.

Mathers, S.J., Terrington, R.L., Waters, C.N., Leslie, A.G., 2014. GB3D - a framework for the bedrock geology of Great Britain. Geoscience Data Journal, 1, 30-42.

McManus, J.F, Oppo, D.W., Cullen, J.L., 1999. A 0.5-Million-Year Record of Millennial-Scale Climate Variability in the North Atlantic. Science, 283, 971-975.

Miller, B. (ed.) 2012. Safety Case for the Disposal of Spent Nuclear Fuel at Olkiluoto - Features, Events and Processes 2012: Posiva Oy. POSIVA 2012-07. 460 p. ISBN 978-951-652-188-9.

Prueher, L.M, Rea, D.K., 1998. Rapid onset of glacial conditions in the subarctic North Pacific region at 2.67 Ma: Clues to causality. Geology, 26, 1027-1030.

Rahmstorf, S., 2002. Ocean circulation and climate during the past 120,000 years. Nature, 419, 207-214.

Rollin, K E., 2002. Assessment of BGS data for ground source heat pump installations in the UK. Internal Report IR/02/196, British Geological Survey, 50 pp.

Shaw, R.P., Auton, C.A, Baptie, B., Brocklehurst, S., Dutton, M., Evans, D.J., Field, L.P., Gregory, S.P, Henderson, E., Hughes, A.J., Milodowski, A.E., Parkes, D., Rees, J.G., Small, J., Smith, N., Tye, A., West, J.M., 2012. Potential Natural Changes and Implications for a UK GDF. British Geological Survey Commissioned Report, CR/12/127, 198 pp.

Siegert, M.J., Dowdeswell, J.A., 2004. Numerical reconstructions of the Eurasian Ice Sheet and climate during the Late Weichselian. Quaternary Science Reviews, 23, 1273-1283.

Westaway, R., Younger, P.L., 2013. Accounting for palaeoclimate and topography: A rigorous approach to correction of the British geothermal dataset. Geothermics, 48, 31-51. 
Figure 1. The reconstructed mean annual air temperature trend for Great Britain over the last $126 \mathrm{kyr}$. This reconstructed temperature trend was used as a basis for the surface temperature histories at each of the 10 localities, where the maximum and minimum temperatures were adjusted, along with the effect of ice sheet presence.

Figure 2. Ground surface temperature histories for the average estimate climate for a) the Weald, which was ice free and where the minimum temperature of $12^{\circ} \mathrm{C}$ below present occurred at the peak of the last glaciation; b) the Southern Uplands where ice cover between 110-102, 76-37 and 34-14.5 kyr BP insulated the land surface from the extremes of air temperature. Hence, despite a minimum MAAT of $17^{\circ} \mathrm{C}$ below present the minimum temperature of $11.9^{\circ} \mathrm{C}$ below present occurred after the ice had retreated.

Figure 3. The ten selected locations across Great Britain for permafrost modelling, overlaid on the 1:625,000 scale bedrock geology. The geology key for this map can be viewed at http://mapapps.bgs.ac.uk/geologyofbritain/home.html.

Figure 4. Permafrost evolution modelling for the Weald, a) derived with the average estimate surface temperature history, b) derived with the cold estimate surface temperature history.

Figure 5. Permafrost evolution modelling for the Southern Uplands, a) derived with the average estimate surface temperature history, b) derived with the cold estimate surface temperature history.

Figure 6. Permafrost evolution model for the Southern Uplands examining the theoretical case of exposure of the land surface to very cold conditions at the onset of a glacial advance before the formation of glacier ice, modelled here as an onset at $34 \mathrm{kyr} \mathrm{BP}$ and exposure for 200 years; a) the average estimate climate where the MAAT was $-17^{\circ} \mathrm{C}$ relative to modern; b) the cold estimate climate where the MAAT was $-27^{\circ} \mathrm{C}$ relative to modern.

Figure 7. Surface temperature history for the average estimate climate for Dartmoor extending back to $212 \mathrm{kyr}$ ago for the period of the last two glacial-interglacial cycles.

Figure 8. Permafrost evolution modelling extending back over the last two glacialinterglacial cycles to $212 \mathrm{kyr}$ BP for Dartmoor, a) derived with the average estimate surface temperature history, b) derived with the cold estimate surface temperature history. Permafrost thicknesses during the last glacial-interglacial cyclical are not affected by the previous cycle.

Figure 9. Future surface temperature prediction for the average estimate climate for Dartmoor. After a period of anthropogenic warming that has receded by $90 \mathrm{kyr}$ AP (BIOCLIM 2001), the climate assumes a repeat of the last glacialinterglacial cycle at $174 \mathrm{kyr}$ AP.

Figure 10. Modelled prediction of permafrost for Dartmoor in a future climate based on the surface temperature prediction in Figure 9, a) derived with the average estimate surface temperature history, b) derived with the cold estimate surface temperature history. Permafrost thicknesses are not significantly altered by the period of anthropogenic warming.

Table 1a. Descriptions of the permafrost modelling locations in southern Britain. The minimum mean annual air temperature (MAAT) for both the average estimate 
(AE) and cold estimate (CE) climates is shown along with periods of ice cover and assumed temperatures at the base of the ice (relative temperature and in brackets, the absolute temperature). A, not to scale diagram, illustrates the bedrock geology beneath the location with depth $(\mathrm{m})$ relative to Ordnance Datum (+ve above sea level) shown on the left and geology (with, in brackets the thermal conductivity in $\mathrm{W} \mathrm{m}^{-1} \mathrm{~K}^{-1}$ ) on the right. The rock unit name (left part of geology code) can be found at http://www.bgs.ac.uk/lexicon/ and the rock description (right part of geology code) can be found at http://www.bgs.ac.uk/data/vocabularies/dictionary.cfm?name=DIC_ROCK_SI GMA.

Table 1b. Descriptions of the permafrost modelling locations in northern Britain. Table contents are as described for Table $1 \mathrm{a}$.

Table 2 Maximum regional, modelled thicknesses of permafrost at the ten locations resulting from the average and cold estimate climates. 


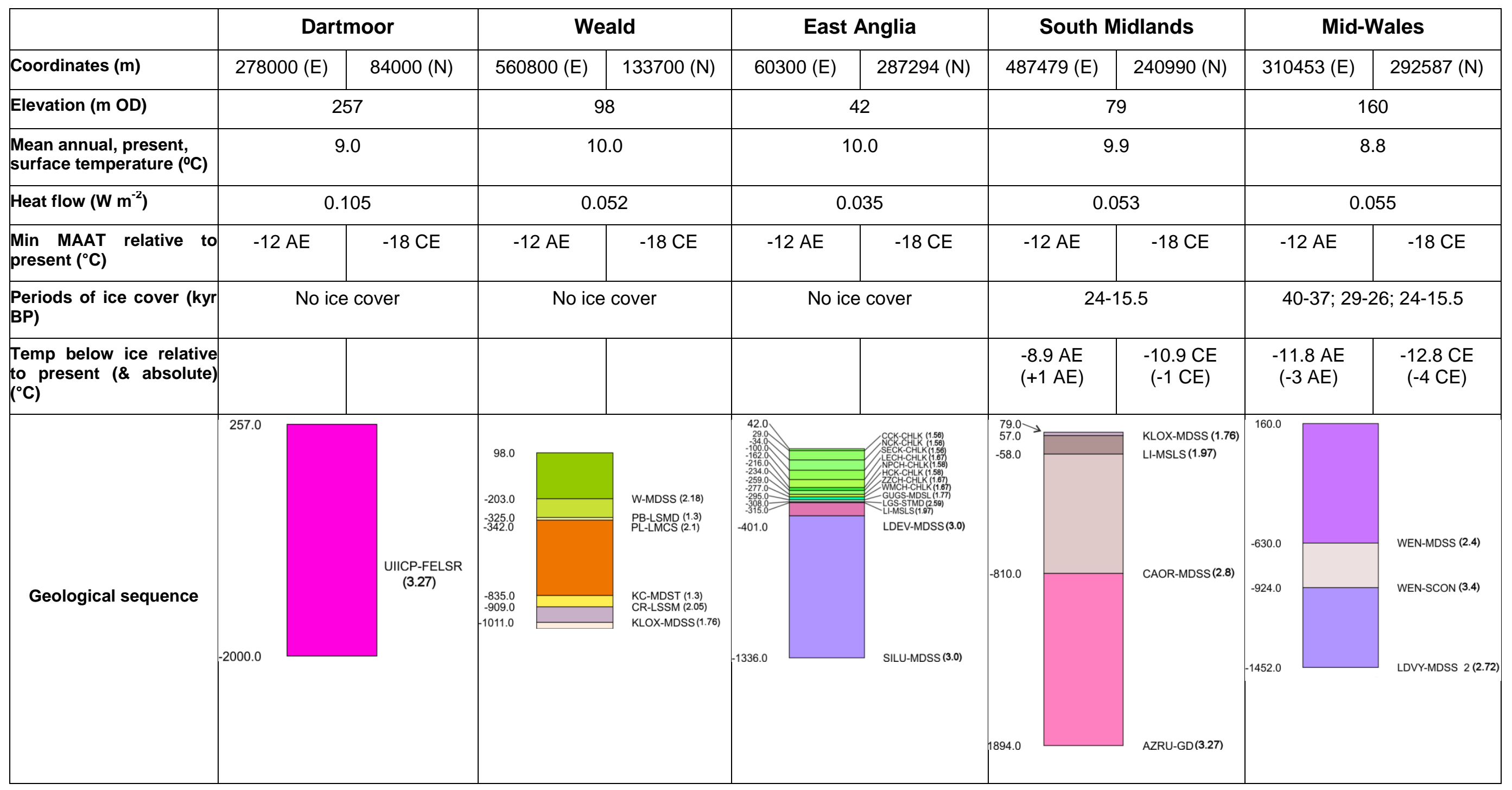




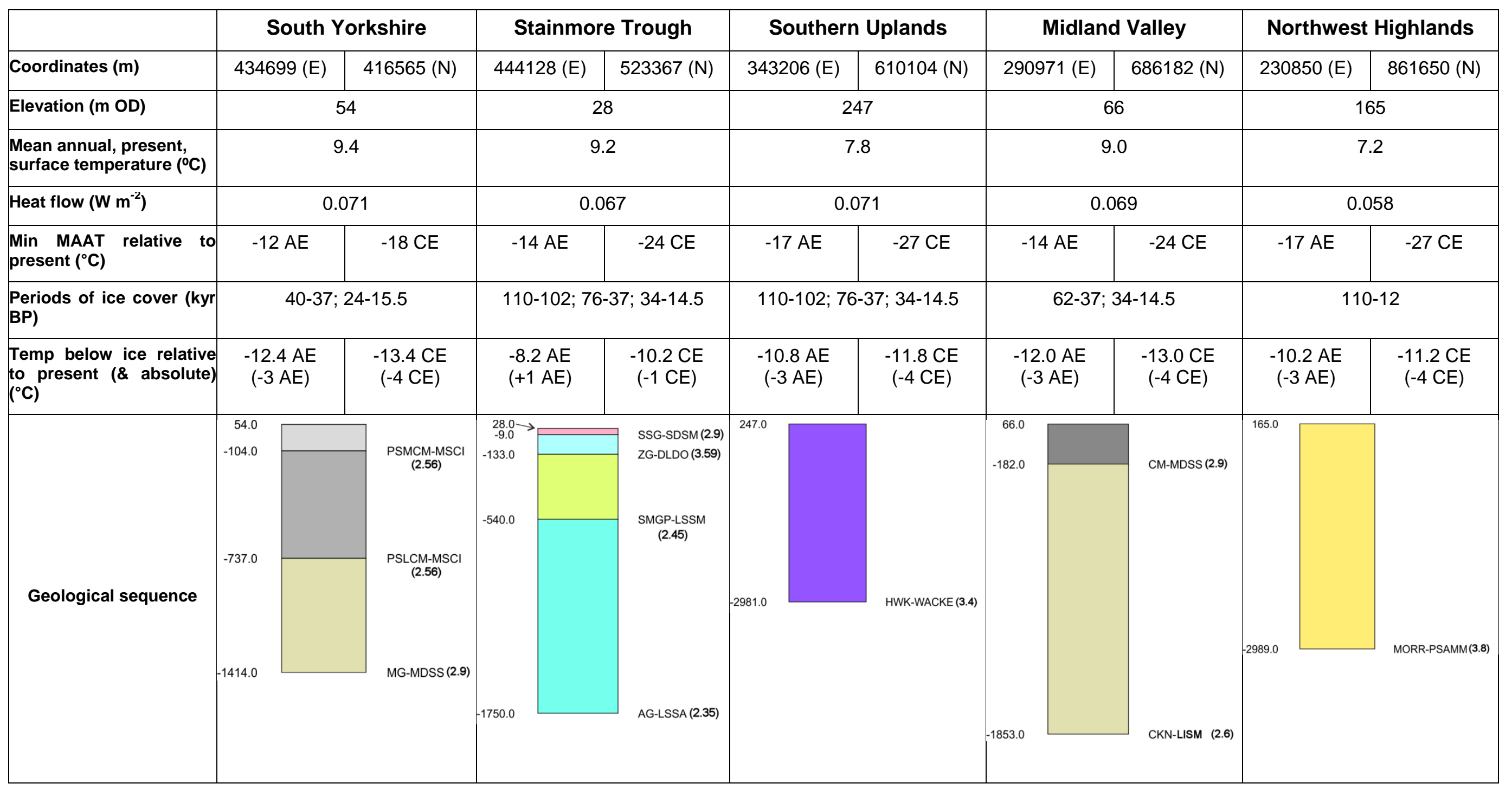




\begin{tabular}{|l|c|c|}
\hline \multicolumn{1}{|c|}{ Location } & $\begin{array}{c}\text { Maximum thickness of } \\
\text { permafrost }(\mathbf{m}) \text { due to } \\
\text { average estimate climate }\end{array}$ & $\begin{array}{c}\text { Maximum thickness of } \\
\text { permafrost (m) due to } \\
\text { cold estimate climate }\end{array}$ \\
\hline Dartmoor & 80 & 220 \\
\hline Weald & 65 & 245 \\
\hline East Anglia & 65 & 245 \\
\hline South Midlands & 30 & 180 \\
\hline Mid-Wales & 105 & 215 \\
\hline South Yorkshire & 90 & 180 \\
\hline Stainmore Trough & 20 & 205 \\
\hline Southern Uplands & 150 & 305 \\
\hline Midland Valley & 110 & 215 \\
\hline Northwest Highlands & 180 & 235 \\
\hline
\end{tabular}

Table 2 
Click here to download high resolution image

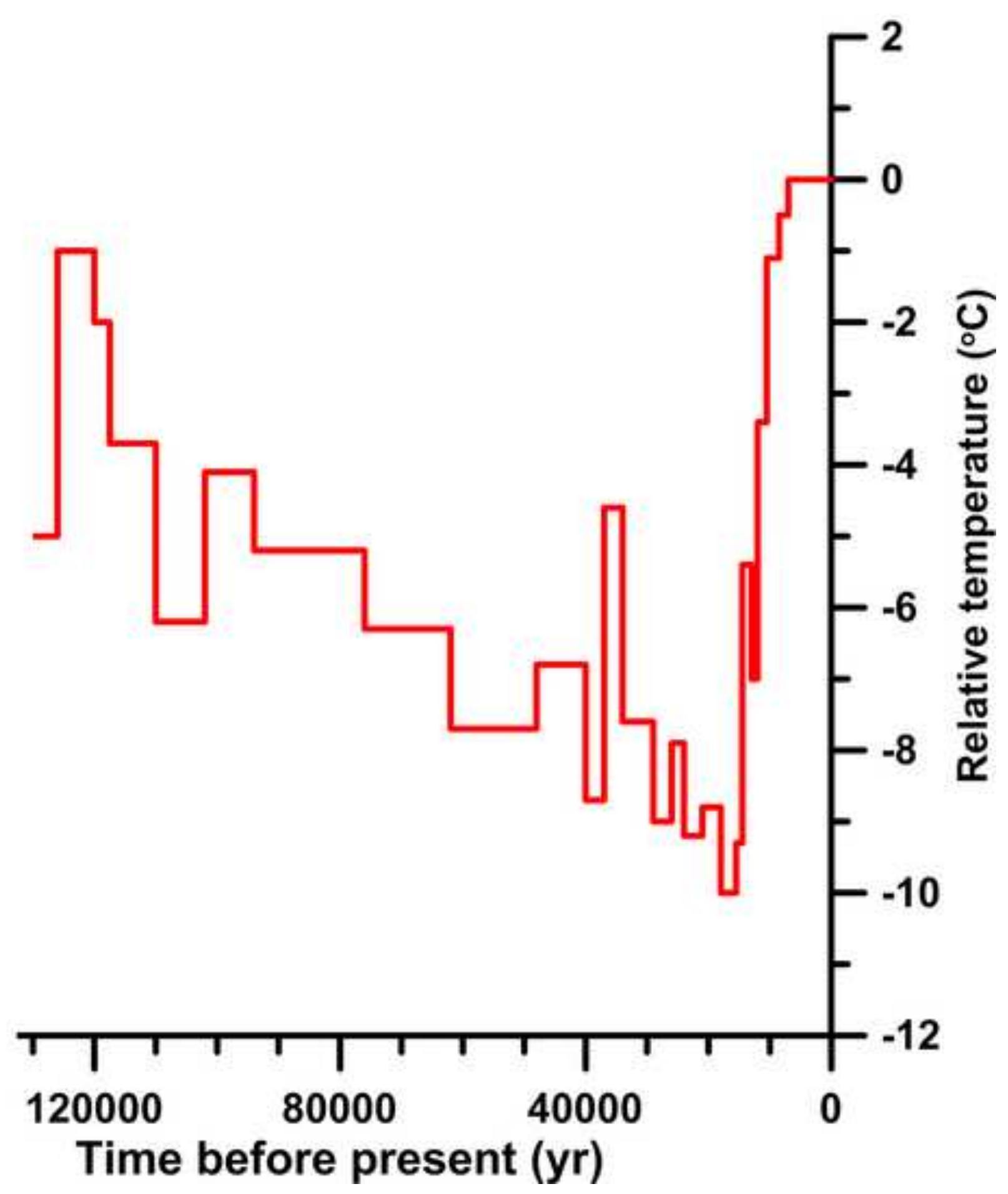




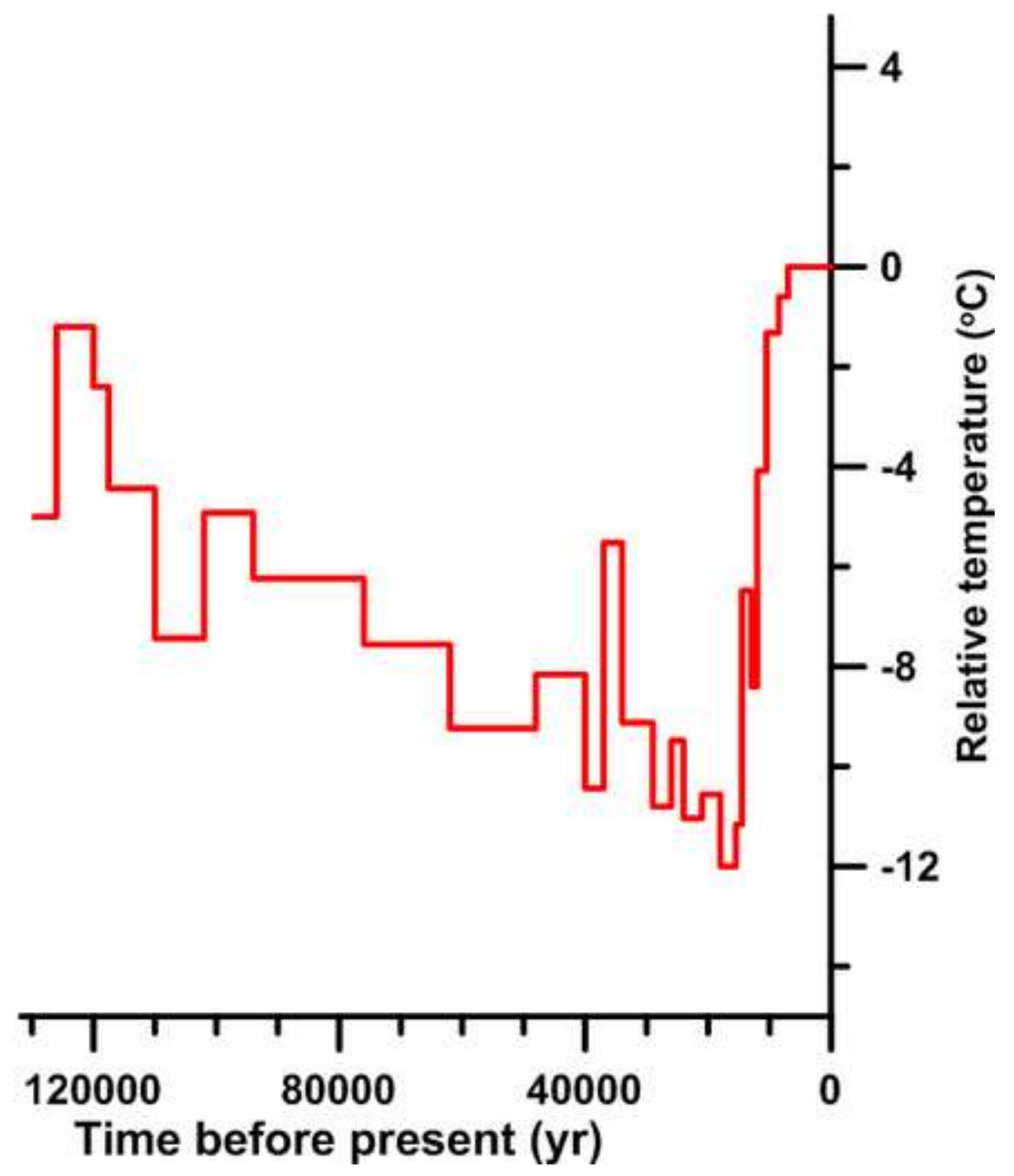




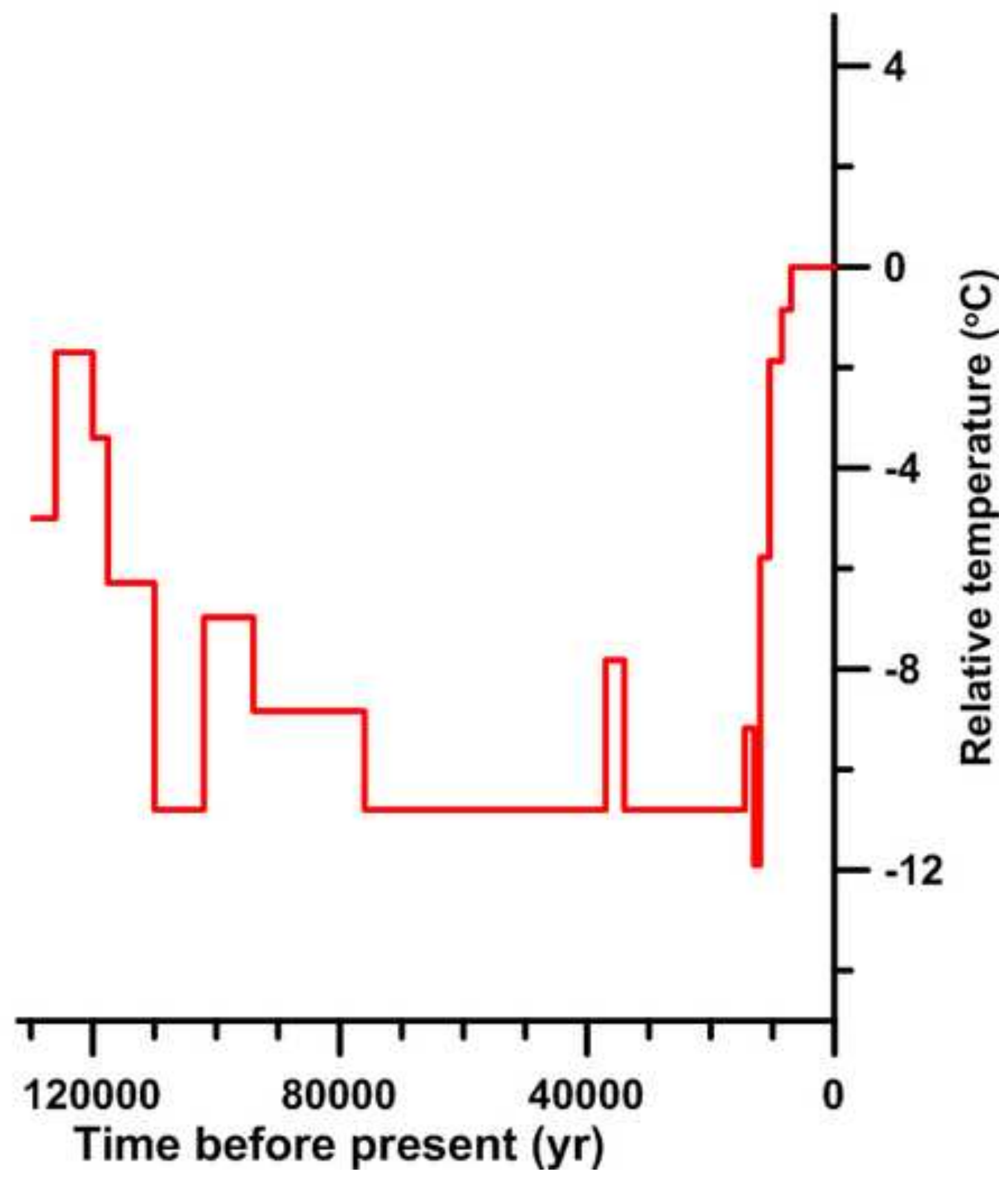




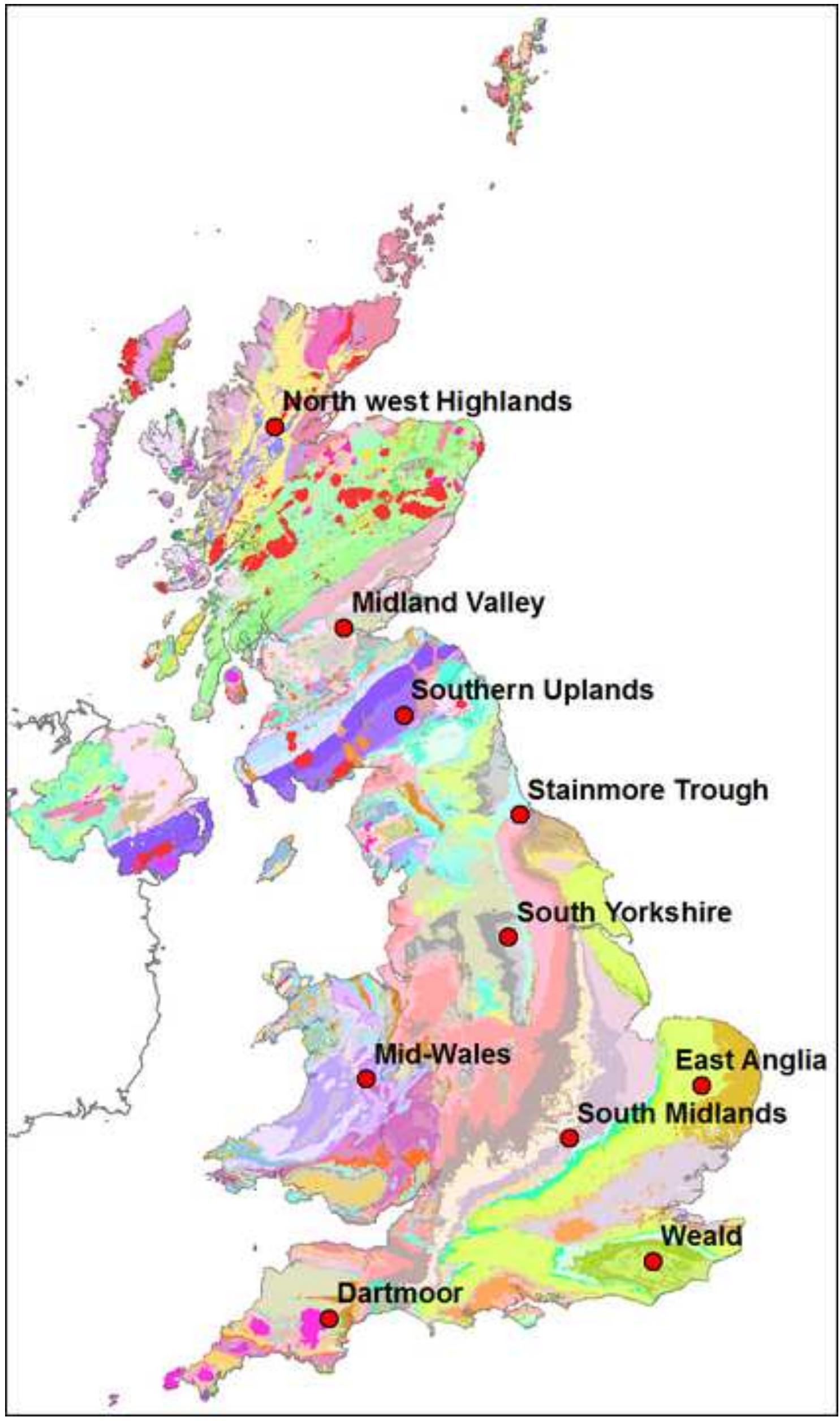


Figure $4 a$
Click here to download high resolution image

Time before present (1000 yrs)

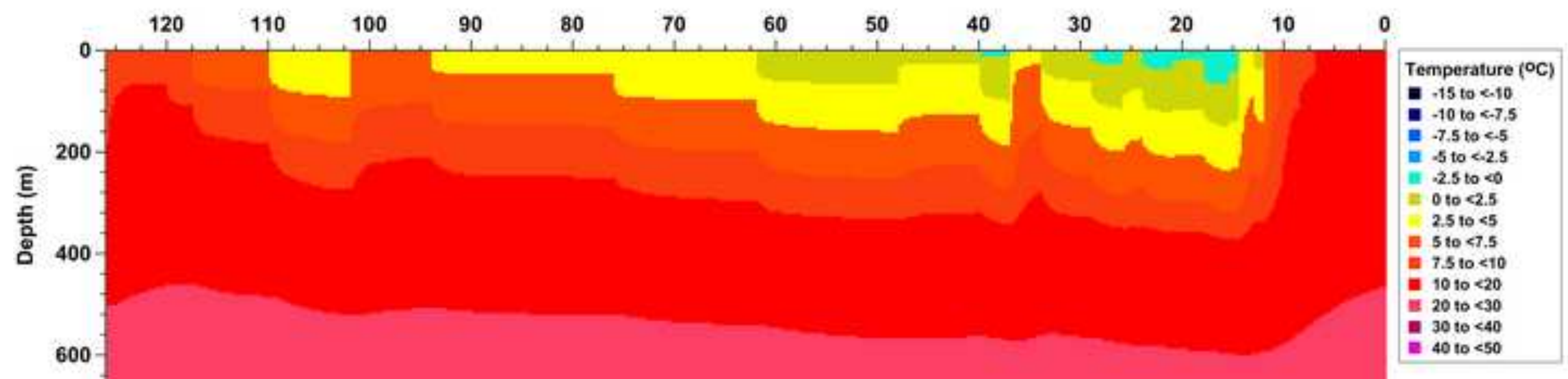


Figure 4b

Click here to download high resolution image

Time before present (1000 yrs)

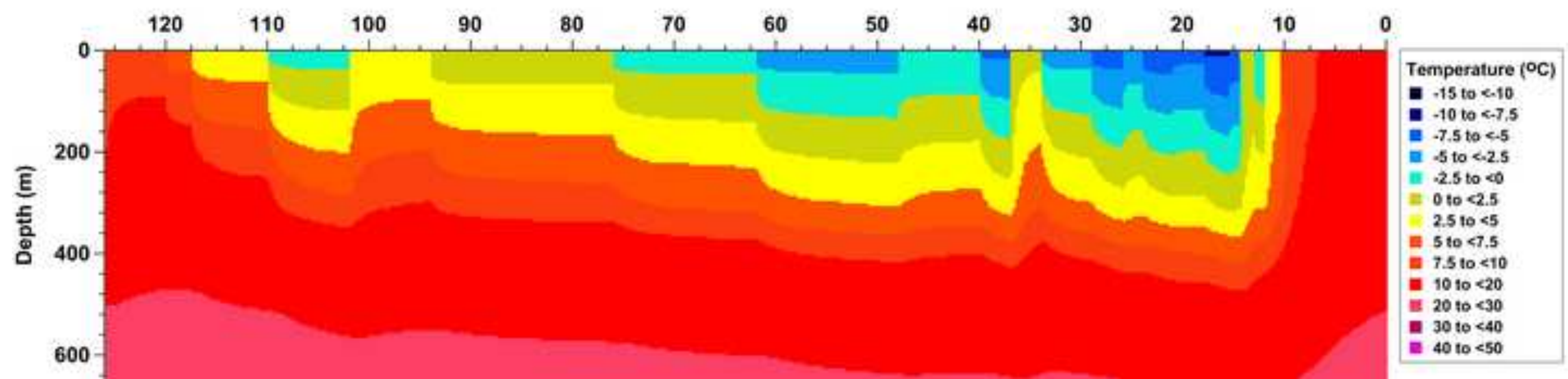


Figure $5 \mathrm{a}$
Click here to download high resolution image

Time before present (1000 yrs)

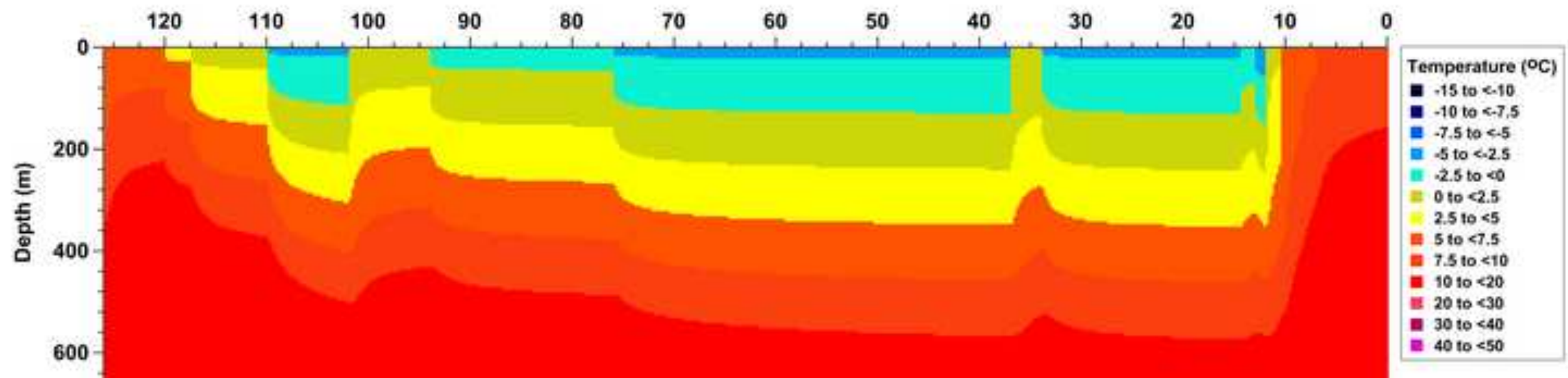


Figure $5 \mathrm{~b}$
Click here to download high resolution image

Time before present (1000 yrs)

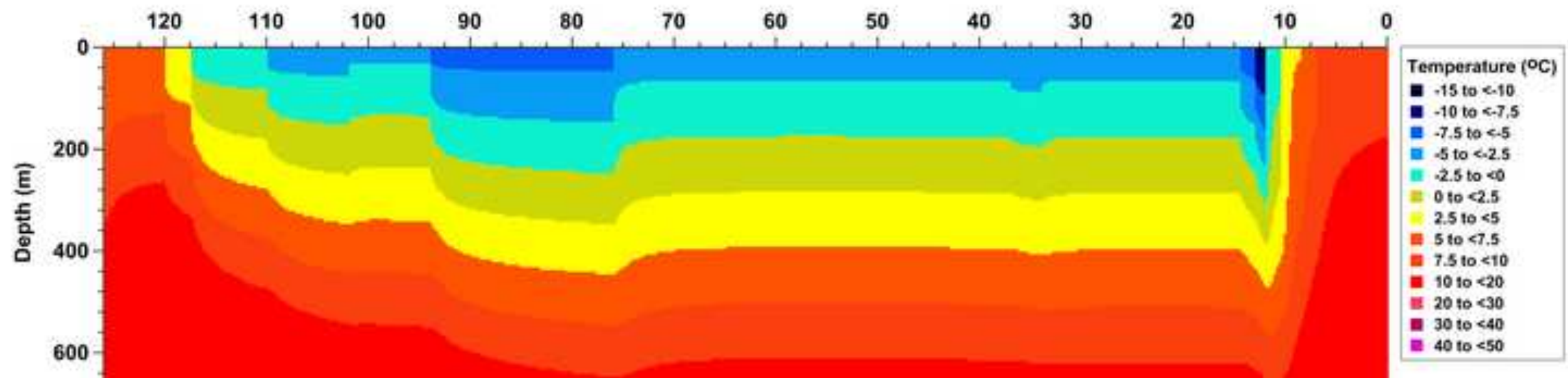




\section{Time before present (1000 yrs)}

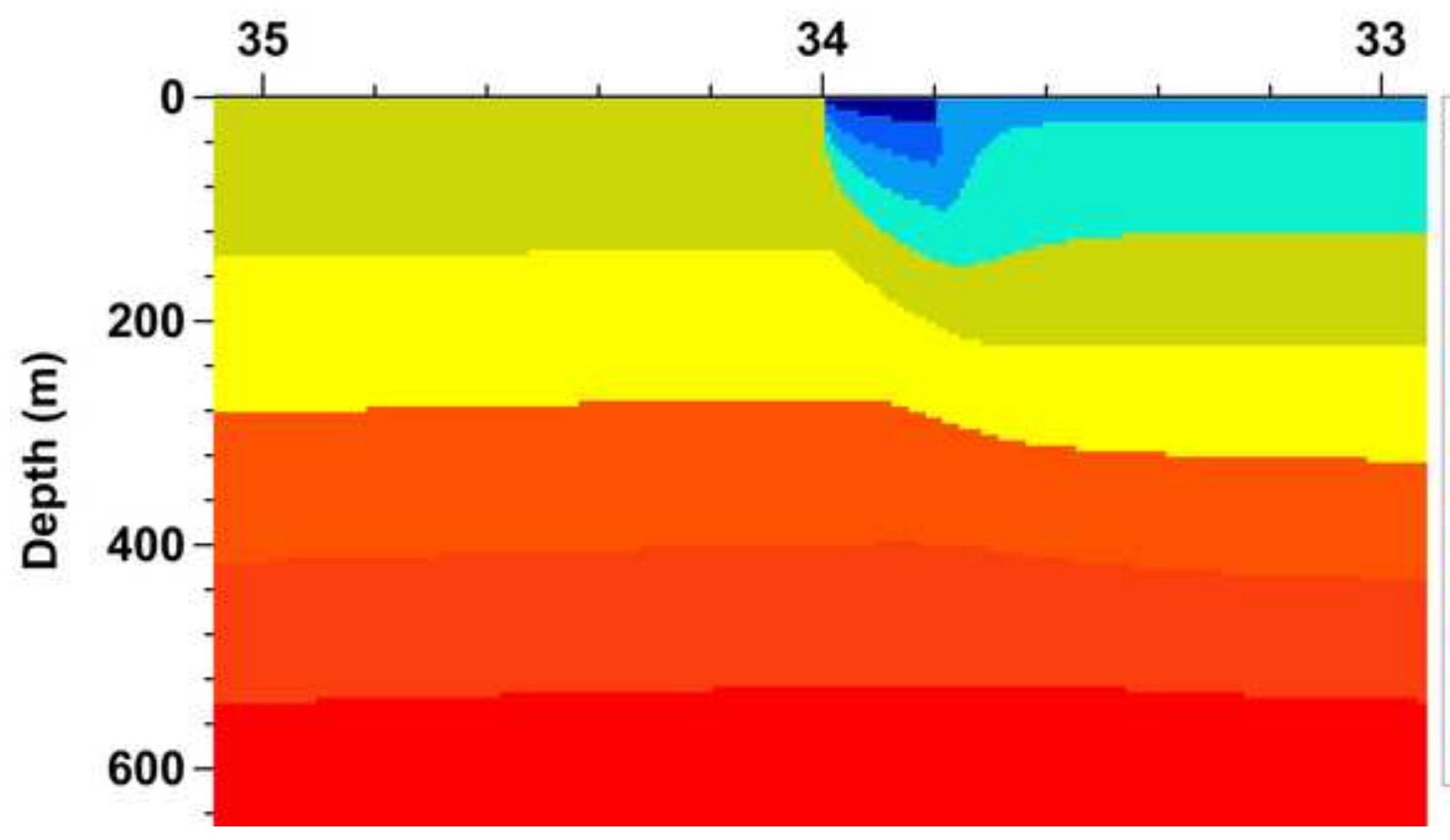

Temperature $\left({ }^{\circ} \mathrm{C}\right)$

- -15 to $<-10$

a -10 to $<-7.5$

-7.5 to $<-5$

E -5 to $<-2.5$

-2.5 to $<0$

0 to $<2.5$

2.5 to $<5$

- 5 to $<7.5$

7.5 to $<10$

- 10 to $<20$

20 to $<30$

- 30 to $<40$

- 40 to $<50$ 


\section{Time before present (1000 yrs)}

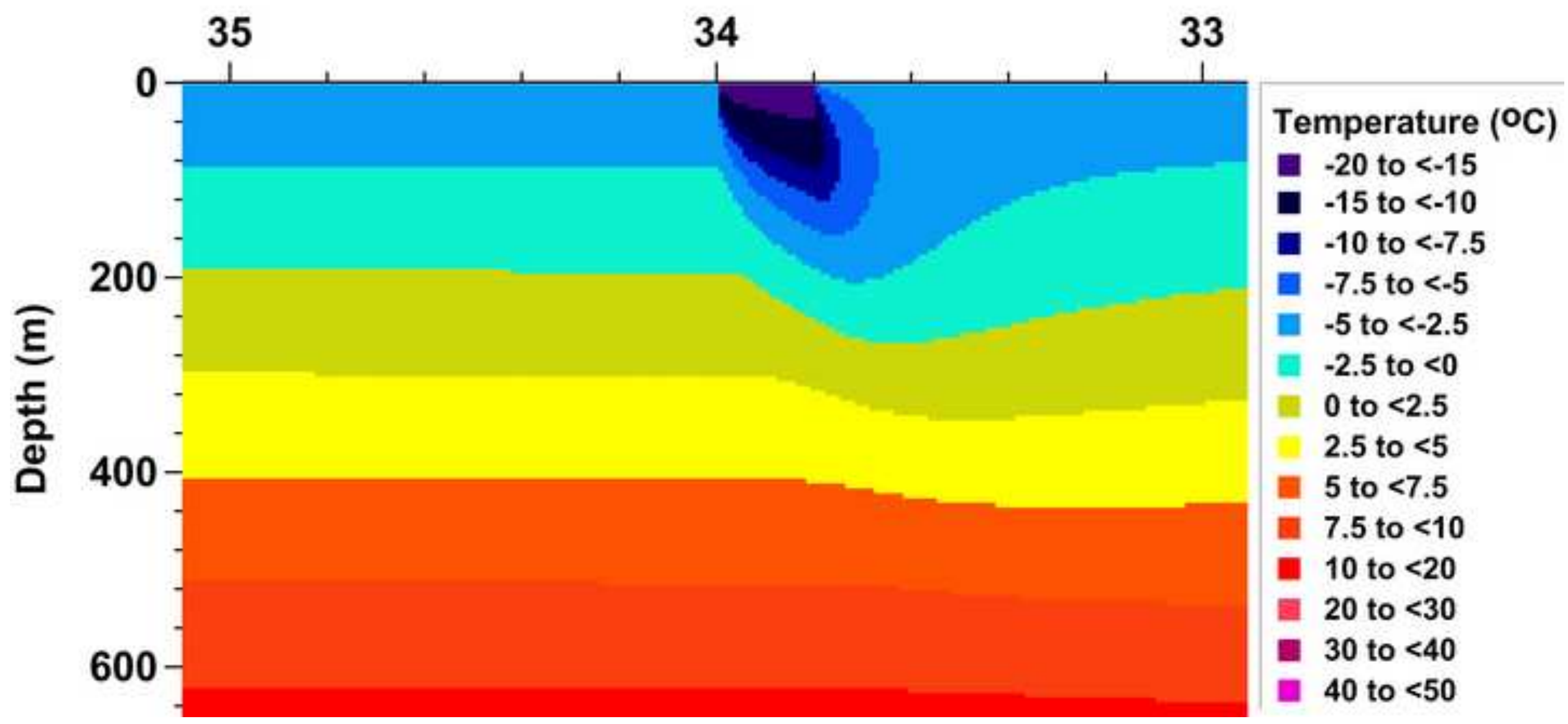


Figure $8 \mathrm{a}$
Click here to download high resolution image

Time before present (1000 yrs)

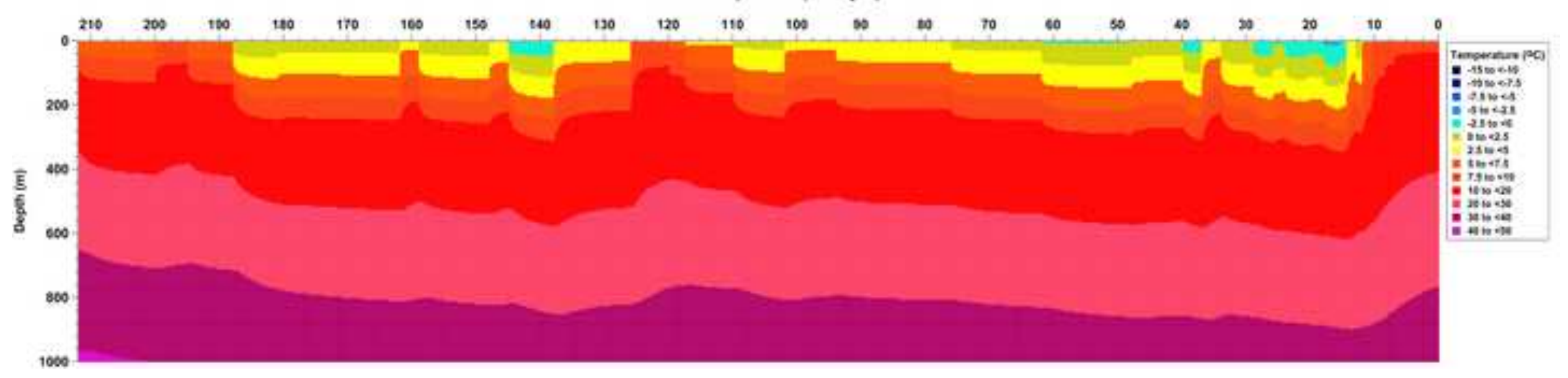




\section{Figure $8 \mathrm{~b}$}

Click here to download high resolution image

Time before present (1000 yrs)

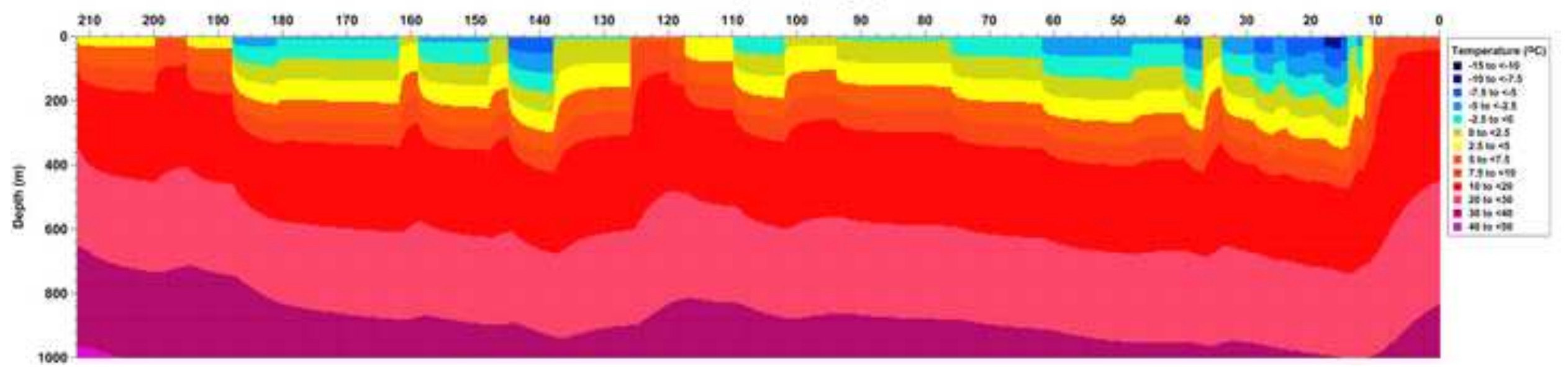




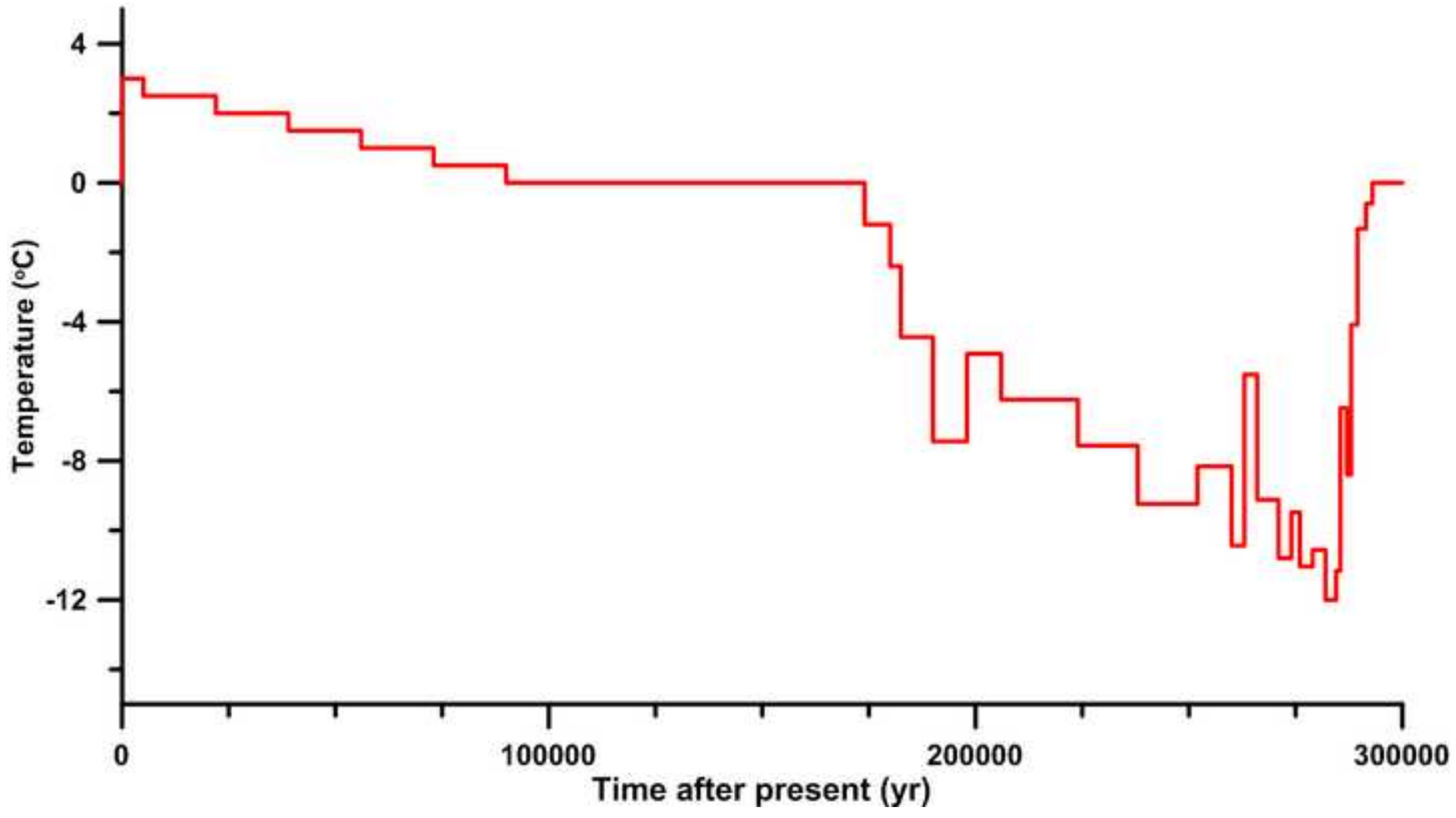


Figure $10 a$
Click here to download high resolution image

Time after present (1000 yrs)

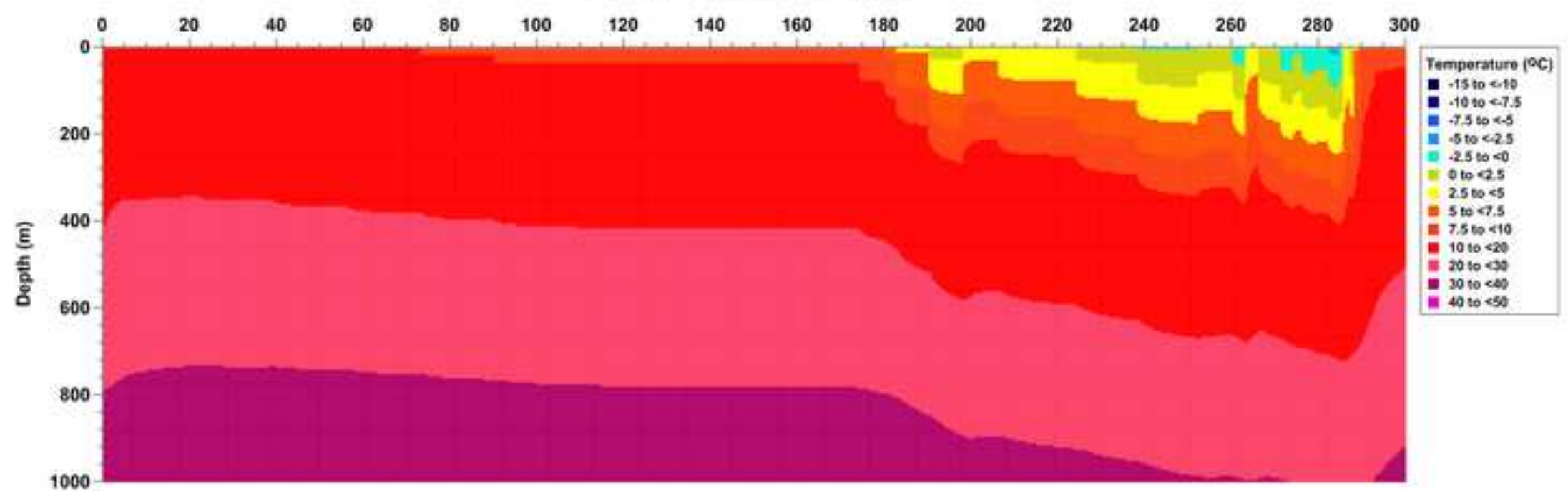


Click here to download high resolution image

Time after present (1000 yrs)

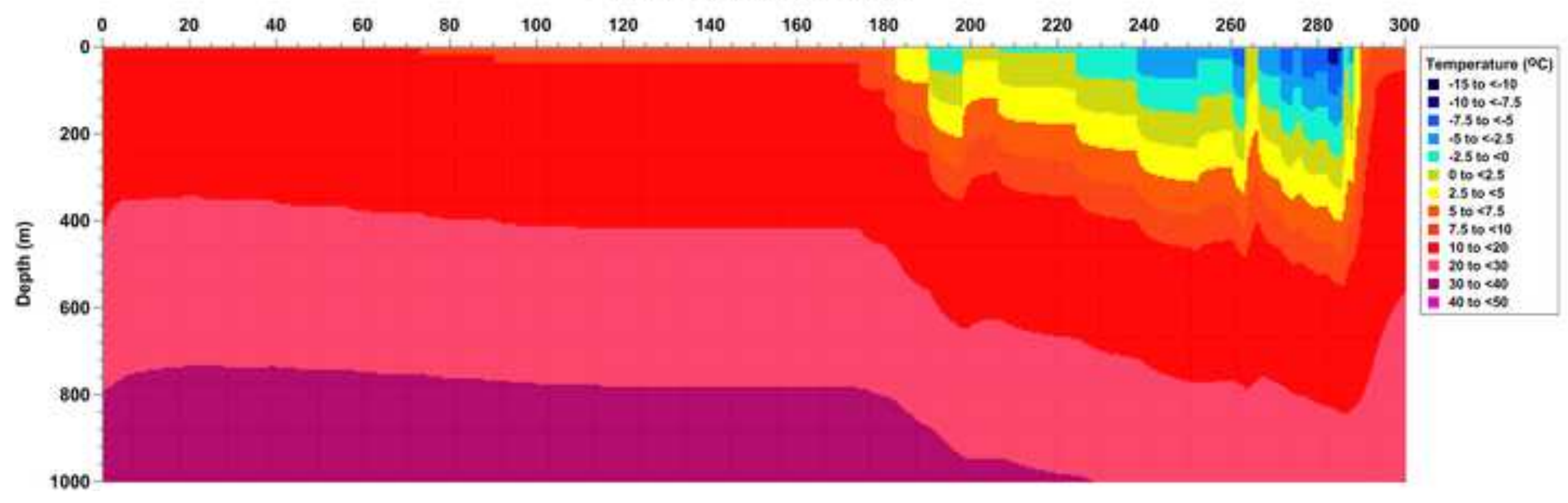

